\title{
GLACIER AND PERMAFROST SIGNALS OF 20TH-CENTURY WARMING
}

\author{
by
}

\author{
Wilf ried Haeberli
}

(Versuchsanstalt für Wasserbau, Hydrologie und Glaziologie, ETH-Zentrum, CH 8092 Zürich,

Gloriastrasse $37 / 39$, Switzerland)

\section{ABSTRACT}

Currently-available evidence of 20th-century warming from glaciers and permafrost is briefly reviewed. The signals are clear and strong: warming of polar firn and permafrost, and mass losses of glaciers at lower latitudes, were most striking towards the middle of the century. The easily observable length-reduction of mountain glaciers confirms the global character of the evolution. A probably intermittent reversal of the trend was observed in places after about 1950.

\section{INTRODUCTION}

Due to the slowness of heat diffusion and the retarding effect of latent heat exchange, secular climatic trends are clearly preserved in mass and temperature changes of glaciers and permafrost. For this reason perennial land-ice bodies are key parameters for climate system monitoring (Wood, 1988). An attempt is here made to mention briefly the available information, outline ideas for their interpretation, and demonstrate the advantages of a comprehensive approach which includes both glaciers and permafrost.

\section{GLACIER GEOMETRY}

Standardized data on changes in surface area, thickness, volume, mass and length of mountain glaciers are being collected internationally and published by the World Glacier Monitoring Service (WGMS) of the International Commission on Snow and Ice (ICSI) within the framework of GEMS/ UNEP, FAGS/ICSU and UNESCO/IHP programmes (Haeberli, 1989). Emphasis is on mass balance (here its specific value, $b$ ) and length changes of glaciers $(\Delta 1)$.

Direct glacier mass-balance observations using glaciological methods (stakes and pits) started mainly after World War II, but data concerning the whole 20th century, predominantly collected by the geodetic/photogrammetric method (repeated precision mapping), are available for the European Alps (Finsterwalder and Rentsch, 1980; cf. Chen and Funk, in press). Mean values of $b$ over the entire period vary between -2 and $-6 \mathrm{dm} \mathrm{a}^{-1}$.

Glacier length variations reflect changes in $b$ after a reaction time which depends on the ratio between the flowline-length in the ablation area and the kinematic wave velocity. Advance and retreat rates of glacier margins are, however, often influenced also by local orographic conditions; mechanically unstable glaciers (surges, calving) and those that are heavily debris-covered must be excluded from direct climatic interpretation. Scatter in $\Delta \mathrm{l}$ values due to orographic complications can be reduced by averaging measurements from more than one glacier and the influence of different reaction times can be taken into account by classifying glaciers according to length. Figure 1 presents data from the Swiss Alps. The overall picture is a pronounced retreat of glacier tongues, the absolute amount being related to glacier length.

From continuity (Paterson, 1981), an assumed initial step change in mass balance $(\Delta b)$ enabling a given $\Delta 1$ can

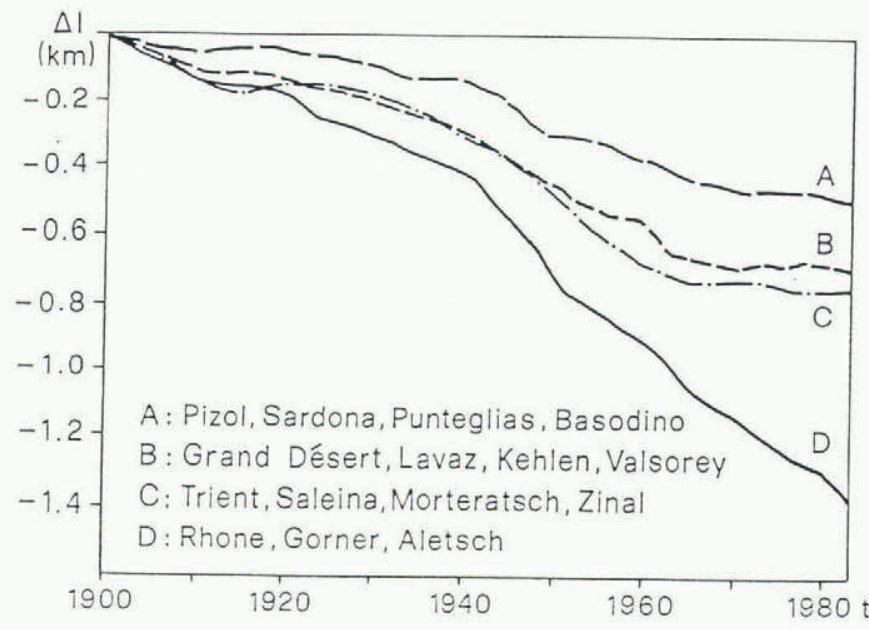

Fig. 1. Length changes of Alpine glaciers since the beginning of the 20th century. Three-year running means are averaged from the indicated glaciers in each of the following size categories: (A) small cirque and mountain glaciers shorter than $2 \mathrm{~km}$, (B) larger cirque and mountain glaciers $2-5 \mathrm{~km}$ long, (C) short valley glaciers $5-10 \mathrm{~km}$ long, and (D) long valley glaciers more than $10 \mathrm{~km}$ long. The four groups reflect balance changes with increasing signal strength, time delay and smoothing: high-frequency (annual) signals show up in category A, decadal trends are clearly visible in $B$ and $C$, whereas D mainly gives secular trends. Data basis: Kasser and others (1986).

be estimated from the ablation at the glacier margin multipled by $\Delta 1 / 1$, where 1 is total glacier length. Values of $\Delta b$ calculated in this way for all categories $\mathrm{A}$ through $\mathrm{D}$ in Figure 1 are -5 to $-10 \mathrm{dm} \mathrm{a}^{-1}$. Roughly half this amount, or -2.5 to $-5 \mathrm{dm} \mathrm{a}^{-1}$, corresponds to the average $b$ value for steadily adjusting glaciers. Hence, the observed glacier retreat confirms the representativity of directly measured $b$ values. With typical Alpine gradients of mass balance with altitude $\left(b^{\prime}, 5\right.$ to $10 \mathrm{dm} \mathrm{a}^{-1}, 100 \mathrm{~m}$ altitude), the observed $\Delta b$ with respect to the past century corresponds to a shift in equilibrium line altitude ( $\triangle \mathrm{ELA})$ of roughly +50 to $+100 \mathrm{~m}$. This result is further confirmed by direct comparison of glacier geometry at the maximum extent of the Little Ice Age and today (Maisch, 1988). Most, if not all, of this change can be explained by an air temperature increase of $+0.5^{\circ}$ to $1{ }^{\circ} \mathrm{C}$ (Kuhn, 1989) as measured on average for the northern hemisphere (UNEP, 1987).

Comparison of glacier mass and length changes at low latitudes with much less complete values from polar regions must take into account climatological aspects and glacier morphology. Changes in precipitation cause strongest ELAshifts under especially dry or wet conditions (Kerschner, 1985). Moreover, $b^{\prime}$ increases by more than one order of magnitude from continental to maritime glaciers (Kuhn, 1981). Because $b$ depends on $\triangle \mathrm{ELA}$ times $b^{\prime}$, its sensitivity 
to climatic changes is generally much higher in maritime than in continental areas. It is therefore not astonishing that principal-component analysis of spatio-temporal distribution patterns classifies long-term glacier mass balances according to "continentality" (Letréguilly and Raynaud, in press) and that glaciers can gain mass as a reaction to increased precipitation despite simultaneously rising air temperature (Mayo and Trabant, 1984). Morphological aspects are less well understood but relate to the hypsography (Furbish and Andrews, 1984) and dynamic response of individual glaciers (cf. Johannesson and others, 1989), as well as probably to radiation-feedback mechanisms (cf. Oerlemans, 1989). Mass loss and retreat of small mountain glaciers were strongest in the first half of the century. This general tendency slowed down considerably and, in humid areas, even reversed after about 1950 (Haeberli and others, 1989).

\section{PERMAFROST GEOMETRY}

Geometric changes of permafrost supersaturated in ice can take place through thaw settlement within the active layer (immediate response) and at the base of the frozen material (delayed response). The response time for basal melting depends on the thickness and the thermal diffusivity of the permafrost (Osterkamp, 1984). It is in the order of decades to centuries for cold/thick (continuous) permafrost and of years to decades for warm/thin (discontinuous) permafrost. The latter is especially sensitive to the observed secular warming and may even completely degrade from the top (fast) as well as from the bottom (slow). Initial attempts have been made to monitor photogrammetrically geometrical changes of rock glaciers, the most striking morphological expression of creeping mountain permafrost (Haeberli and Schmid, 1988). The investigated Alpine permafrost appears to be slowly melting as a consequence of 20th-century warming. Thickness changes of permafrost are smaller than of glacier ice by one to two orders of magnitude and, hence, long-term and high-precision photogrammetry is required. Systematic measurements in various mountain ranges should therefore be initiated as soon as possible, to detect ongoing changes within reasonable time.

\section{PERMAFROST TEMPERATURE}

Temperature profiles in saturated/impermeable permafrost can be interpreted on the basis of heat diffusion theory (Gold and Lachenbruch, 1973). Extended drilling activity for oil prospecting in polar permafrost furnishes increasing evidence on 20th-century warming; much less information is available about effects at low latitudes or high altitudes. International inventories of borehole temperatures in permafrost are not yet available but may soon be realized by the International Permafrost Association (IPA).

Boreholes in thick/continuous permafrost commonly, but not universally, show pronounced geothermal anomalies within the uppermost $100-200 \mathrm{~m}$. Maximum departure from steady-state temperature profiles in the Alaskan Arctic is observed at about $50-25 \mathrm{~m}$ depth and reaches values of $1-2^{\circ} \mathrm{C}$, corresponding to secular surface warming of about $2-4^{\circ} \mathrm{C}$ - the same general magnitude as the warming of air temperatures during the past 100 years derived from nearby weather stations (Lachenbruch and others, 1988). Signs of more recent, decadal cooling by roughly half the secular warming effect (increased temperature gradient/heat flow above about $50-25 \mathrm{~m}$ depth) may be partially attributed to the construction of gravel pads in connection with the drilling operation. Geothermal borehole information from mountain permafrost at lower latitudes is still extremely rare but also shows evidence of recent warming. Rock glacier permafrost in the Kluane Range, Yukon Territory, quickly warmed up and degraded from the top as well as from the bottom (Johnson and Nickling, 1979). A borehole on Plateau Mountain, Alberta, indicates a temperature gradient/heat flow near zero in permafrost more than $150 \mathrm{~m}$ thick (Harris, 1988). Geothermal analysis of a borehole through the permafrost of an active rock glacier in the Swiss Alps shows increased heat flow down to an unfrozen layer at $52 \mathrm{~m}$ depth, perhaps reflecting cooling since about 1950, but also a heat flow inversion below $55 \mathrm{~m}$ which may indicate that existence of deep-seated relic permafrost from the Little Ice Age (Vonder Mühll and Haeberli, in press). Convective heat transport through circulating groundwater may play an important role in all these cases.

\section{TEMPERATURES, MELT LAYERS AND ISOTOPES IN COLD FIRN}

Heat diffusion theory combined with flow modelling must be applied to interpret temperature profiles within cold firn areas where percolation of meltwater is limited or absent. As with permafrost temperatures, considerable bore-hole evidence and sophisticated analyses are available from polar regions, but information about low latitudes is almost completely lacking. All over the accumulation area of Greenland, as well as in marginal parts of Antarctica, temperature gradient/heat flow is clearly inverted between 50 to $200 \mathrm{~m}$ depth (Robin, 1983). The magnitude of these anomalies is comparable with those observed in polar permafrost, confirming the pronounced secular warming trend. The more recent decadal cooling trend can also be found in many boreholes of the Greenland ice sheet in qualitative accordance with the temperature history as derived from the oxygen-isotope records (cf. Johnsen, 1977; Clausen and others, 1987). The influence of latent heat effects from refrozen melt layers is usually neglected in analyses of firn temperature. Such refrozen melt layers represent important evidence of meteorological conditions at the surface during dry weather (Beck and others, 1988) and, hence, are complementary to the oxygen-isotope record which reflects precipitation temperature. Stratigraphic investigation of firn cores from the Canadian Arctic (Koerner, 1977; cf. also Herron and others, 1981) reveals a pronounced increase in melt-layer frequency since the middle of the 19th century and especially in the first half of the 20th century. By modelling the thermal regime of an Arctic valley glacier, Blatter (1987) shows the measured firn temperature profiles to be well in accordance with air temperatures rising by about $3{ }^{\circ} \mathrm{C}$ until the 1940 s. An attempt to compare firn temperatures at polar and temperate latitudes is being made at the Colle Gnifetti drill site in the Swiss Alps (Haeberli and Funk, in press). Despite the fact that melt-layer frequency in the firn cores clearly increases towards the middle of the 20th century (Schotterer and others 1981), the temperature profile measured on this $-14^{\circ} \mathrm{C}$ firn saddle at $4450 \mathrm{~m}$ a.s.l. is close to steady-state conditions. The coupling of melt-layer formation, protection against wind erosion and accumulation of cold snow (Alean and others, 1984) perhaps helps to explain why warming of cold firn as a response to 20th-century atmospheric warming appears to be much less pronounced on low-latitude mountains than in Arctic regions.

\section{CONCLUSION AND RECOMMENDATION}

Taken as complex and integrated climatic evidence which is independent of instrumental meteorological measurements, glacier and permafrost signals of 20th-century warming are coherent: warming of polar firn and permafrost is pronounced and mass loss/retreat of mountain glaciers is striking all over the world. Effects appear to be strongest at high latitudes and signs of a probably intermittent reversal of the trend after about 1950 are clearly visible. The latest development (1980s) is still hidden in as yet unpublished data as well as in natural noise such as seasonal temperature variations in permafrost or delayed response of glacier tongues.

A global view can be obtained only by combining various pieces of evidence. Comparability of data, however, suffers from the uneven regional distribution of such evidence. More numerous, systematic and internationally coordinated measurements should be carried out in permafrost and cold firn at low latitudes and many more glaciers should be monitored at high latitudes. The lack of information from the southern hemisphere outside Antarctica is especially severe and should be overcome as soon as possible. So far, the length reduction of mountain glaciers still remains the most easily detectable, unequivocal proof 
from cold regions that fast and worldwide secular climatic change is taking place. This often-underestimated evidence deserves more attention and intensified analysis.

\section{REFERENCES}

Alean, J., W. Haeberli, and B. Schädler. 1984. Snow accumulation, firn temperature and solar radiation in the area of the Colle Gnifetti core drilling site (Monte Rosa, Swiss Alps): distribution patterns and interrelationships. $Z$. Gletscherkd. Glazialgeol., 19(2), 1983, 131-147.

Beck, N., D. Wagenbach, and K.O. Münnich. 1988. Laboratory experiments on the formation of solar radiation induced melt layers in dry snow, $Z$. Gletscherkd. Glazialgeol., 24(1), 31-40.

Blatter, H. 1987. On the thermal regime of an Arctic valley glacier: a study of White Glacier, Axel Heiberg Island, N.W.T., Canada. J. Glaciol., 33(114), 200-211.

Clausen, H.B., N.S. Gundestrup, S.J. Johnsen, R. Bindschadler, and J. Zwally. 1988. Glaciological investigations in the Crête area, central Greenland: a search for a new deep-drilling site. Ann. Glaciol., 10, 10-15.

Finsterwalder, R. and H. Rentsch. 1980. Höhenänderung von Ostalpengletschern im Zeitraum 1969-1979. Z. Gletscherkd. Glazialgeol., 16(1), 111-115.

Furbish, D.J. and J.T. Andrews. 1984. The use of hypsometry to indicate long-term stability and response of valley glaciers to changes in mass transfer. J. Glaciol., 30(105), 199-211.

Gold, L.W. and A.H. Lachenbruch. 1973. Thermal conditions in permafrost - a review of North American literature. In Permafrost... Second International Conference on Permafrost... 1973. Yakutsk, U.S.S.R. North American Contribution. Washington, DC, National Academy of Sciences, 3-23.

Haeberli, W. and W. Schmid. 1988. Aerophotogrammetrical monitoring of rock glaciers. In Senneset, K., ed. Permafrost. Fifth International Conference. August 2-5. 1988. Proceedings. Vol. 1. Trondheim, Tapir Publishers, 764-769.

Haeberli, W., P. Müller, P. Alean, and H. Bösch. 1989. Glacier changes following the Little Ice Age - a survey of the international data basis and its perspective. In Oerlemans, J., ed. Glacier fluctuations and climatic change. Dordrecht, Kluwer Academic Publishers, 77-101.

Harris, S.A. 1988. The alpine periglacial zone. In Clark, M.J., ed. Advances in periglacial geomorphology. Chichester, etc., John Wiley and Sons, 369-413.

Herron, M.M., S.L. Herron, and C.C. Langway, jr. 1981. Climatic signal of ice melt features in southern Greenland. Nature, 293(5831), 389-391.

Johannesson, T., C.F. Raymond, and E.D. Waddington. 1989. A simple method for determining the response time of glaciers. In Oerlemans, J., ed. Glacier fluctuations and climatic change. Dordrecht, Kluwer Academic Publishers, 343-352.

Johnson, J.P., $j r$, and W.G. Nickling. 1979. Englacial temperature and deformation of a rock glacier in the Kluane Range, Yukon Territory, Canada. Can. J. Earth Sci., 16(12), 2275-2283.
Johnsen, S.J. 1977. Stable isotope profiles compared with temperature profiles in firn with historical temperature records. International Association of Hydrological Sciences Publication 118 (Symposium at Grenoble 1975 - Isotopes and Impurities in Snow and Ice), 388-392.

Kasser, P., M. Aellen, and H. Siegenthaler. 1986. Die Gletscher der Schweizer Alpen, 1977/78 und 1978/79. Zürich, Gletscherkommission der Schweizerischen Naturforschenden Gessellschaft. (Glaziologisches Jahrbuch. Bericht 99 and 100.)

Kerschner, H. 1985. Quantitative palaeoclimatic inferences from lateglacial snowline, timberline and rock glacier data, Tyrolean Alps, Austria. Z. Gletscherkd. Glazialgeol., 21, 363-369.

Koerner, R.M. 1977. Devon Island ice cap: core stratigraphy and paleoclimate. Science, 196(4285), 15-18.

Kuhn, M. 1981. Climate and glaciers. International Association of Hydrological Sciences Publication 131 (Symposium at Canberra 1979 - Sea Level, Ice and Climatic Change), 3-20.

Kuhn, M. 1989. Reponse of the equilibrium line altitude to climate fluctuations: theory and observations. In Oerlemans, J., ed. Glacier fluctuations and climatic change. Dordrecht, Kluwer Academic Publishers, 407-417.

Lachenbruch, A.H., T.T. Cladouhos, and R.W. Saltus. 1988. Permafrost temperature and the changing climate. In Senneset, K., ed. Permafrost. Fifth International Conference. August 2-5, 1988. Proceedings. Vol. 3. Trondheim, Tapir Publishers, 9-17. (Frost i Jord 27.)

Letréguilly, A. and L. Reynaud. In press. Space and time distribution of glacier mass balance in the Northern Hemisphere. Arct. Alp. Res.

Maisch, M. 1988. Die Veränderungen der Gletscherflächen und Schneegrenzen seit dem Hochstand von 1850 im Kanton Graubünden (Schweiz). Ann. Geomorphol. Supplement 70, 113-150.

Mayo, L.R. and D.C. Trabant. 1984. Observed and predicted effects of climatic change on Wolverine Glacier, southern Alaska. Fairbanks, AK, University of Alaska. School of Agriculture and Land Resources Management, 114-123. (Miscellaneous Publication 83-1.)

Oerlemans, J. 1988. Simulation of historic glacier variations with a simple climate-glacier model, J. Glaciol., 34(118), 333-341.

Osterkamp, T.E. 1984. Response of Alaskan permafrost to climate. In Permafrost. Fourth International Conference. July 17-22, 1983. Final proceedings. Washington, National Academy Press, 145-152.

Paterson, W.S.B. 1981. The physics of glaciers. Second edition. Oxford, etc., Pergamon Press.

Robin, G. de Q. 1983. The climatic record in polar ice sheets. Cambridge, etc., Cambridge University Press.

Schotterer, U., W. Haeberli, W. Good, H. Oeschger, and H. Röthlisberger. 1981. Datierung von kaltem Firn und Eis in einem Bohrkern vom Colle Gnifetti, Monte Rosa. Jahrbuch der Schweizerischen Naturforschenden Gesellschaft. Wissenschaftlicher Teil, 1978, 48-57.

United Nations Environment Programme. 1987. Environmental data report. London, Monitoring and Assessment Research Center.

Wood, F.B., jr. 1988. The need for systems research on global climate change. Systems Research, 5(3), 225-240. 